\title{
FORMALNE ZWIĄZKI MIĘDZY POWINNOŚCIĄ A DOBREM ROZWAŻANIA NA MARGINESIE PRAC HENRYKA ELZENBERGA
}

\begin{abstract}
FORMAL RELATIONS BETWEEN OUGHT AND GOOD: SOME REFLECTIONS IN THE MARGINS OF HENRYK ELZENBERG'S WORKS

The paper presents a relative preference semantics for multimodal logic of good and ought inspired by the axiological writings of Henryk Elzenberg. Its central concept is the act of preference between alternative possibilities performed by a metaempirical will, guided only by pure reasons. In semantics, the act of a metaempirical will is modeled using an orderly relation between possible worlds. Using this logic, I formalize some relationships between good and ought posited by Elzenberg.

Keywords: value and ought, formal axiology, deontic logic, relative preference semantic, Henryk Elzenberg
\end{abstract}

Chociaż Henryk Elzenberg interesował się ogólną formą pojęć etycznych, to w swoich analizach nie stosowal środków czysto formalnych. W latach 30. i 40. nie były one jeszcze dostatecznie wykształcone, a nawet gdyby były, to biorąc pod uwagę jego chłodny stosunek do twórczej pod tym względem Szkoły Lwowsko-Warszawskiej, można wątpić, czy by po nie sięgną. Warto jednak zapytać, jaka logika powinności - czy też może logika wartości kryje się $\mathrm{w}$ jego pracach aksjologicznych. Pionierską próbę rekonstrukcji myśli Elzenberga za pomocą nowoczesnej logiki deontycznej podjął Bogusław Wolniewicz (1986). W artykule pójdziemy tym tropem, ale stawiając sobie skromniejsze zadanie. Nie będziemy pytali o logikę pojęć etycznych zawartą implicite w pismach Elzenberga. Interesować nas będzie logika pojęć etycz-

* Katedra Logiki i Metodologii Nauk, Uniwersytet Wrocławski, ul. Koszarowa 3/20, 51-149 Wrocław, e-mail: marcin.drofiszyn@uwr.edu.pl, ORCID: https://orcid.org/oooo0003-0518-5721. 
nych, którą można zbudować, inspirując się jego przemyśleniami. Nie będziemy drobiazgowo rekonstruować poglądów Elzenberga, ponieważ nie doszedł on nigdy do spójnego systemu przekonań etycznych. Stale napotykał nowe trudności, które podważały jego poczucie słuszności powziętych ustaleń. Niemniej wykonał imponującą i wartościową pracę analityczną i warto z niej skorzystać ${ }^{1}$ by nie budować systemów logiki etycznej bez jakiegokolwiek ugruntowania filozoficznego.

Mówiąc konkretnie, chcielibyśmy sięgnąć do pomysłów Elzenberga na temat związków między pojęciami powinności bytu i dobra moralnego. Jak wiadomo, ogólną formą logiczną pierwszego z tych pojęć zajmuje się logika deontyczna, a drugiego - logika dobra. Interesujące byłoby znalezienie związków, które pozwoliłyby połączyć logikę deontyczną z logiką aksjologiczną w jedną multimodalną logikę deontyczno-aksjologiczną. Chcielibyśmy, inspirując się przemyśleniami Elzenberga, znaleźć propozycje możliwych aksjomatów dla tego typu logiki.

\section{POWINNOŚĆ}

Jak wiadomo, Elzenberg w punkcie wyjścia swoich badań z zakresu aksjologii formalnej postawił pojęcie powinności bytu i za jego pomocą zdefiniował pojęcie wartości perfekcyjnej ${ }^{2}$. Pisal: „przedmiot wartościowy w sensie perfekcyjnym to przedmiot taki, jaki powinien być" (Elzenberg 2002a: 135). A gdyby, zamiast o rzeczach i ich wartości, mówić o stanach rzeczy będących na sposób wartościowy, to definicję Elzenberga można by wyrazić słowami: dobrze jest, gdy jest tak, jak powinno być. To, że pewna cecha, zwana cechą wartościotwórczą, w pewnych okolicznościach przysługuje pewnemu przedmiotowi, sprawia, że jest tak, jak powinno być. Jeśliby z kolei dobro uznać za najogólniejszą wartość, to dobry stan rzeczy określilibyśmy jako ten, który zachodzi, a zarazem jest powinny. W świetle tych uwag logikę dobra można w istocie sprowadzić do logiki powinności. Przy czym musiałaby to być logika

\footnotetext{
${ }^{1}$ W pełni zgadzamy się z Ryszardem Wiśniewskim (1989: 81), który o dorobku Elzenberga pisał: „Elzenberg jest aksjologiem, który usiłował dojść do systemu, lecz uwikławszy się w rozmaite trudności, zdołał ukazać aksjologię in statu nascendi, w całej jej złożoności. Ukazał swoje zmaganie się z przedmiotem aksjologii, a przy okazji zostawił następcom sporo interesujących krytyk, sugestii badawczych i analiz".

${ }^{2}$ Wartością perfekcyjną dla Elzenberga jest to, co budzi cześć, co ma godność i przeciwstawia się wartości utylitarnej, którą jest to, co jedynie zaspokaja jakąś potrzebę lub czyjeś pragnienie (Elzenberg 2002a: 127-130). Dalej, mówiąc o wartości, będziemy mieć na myśli wartość w tym pierwszym znaczeniu.
} 
powinnych stanów rzeczy, a nie powinnych czynów czy obowiązków. Tę pierwszą trzeba ujmować jako logikę zdaniową, natomiast pozostałe mogą być badane jako logiki nazw czynów (logika obowiązków byłaby wówczas logiką nazw czynów zrelatywizowanych do pewnych podmiotów).

Dla Elzenberga było jasne, że skoro powinno być tak a tak, to stąd rodzi się powinność uczynienia tego takim to a takim. Jeśli zaś można dodatkowo znaleźć sprawcę, w którego mocy jest uczynić to takim a takim, wówczas powstaje obowiązek, aby podmiot ten sprawil, by było tak a tak. Dlatego pojęcie powinności bytu jest pierwotne, natomiast pojęcia powinności czynu i obowiązku są wtórne. Pojęcie powinności bytu jest tu zatem pojęciem podstawowym aksjologii. Elementarną normę wyrażającą powinność bytu: „powinno być tak a tak” będziemy oznaczać za pomocą „Op”, gdzie O jest operatorem powinności, a $p$ symbolem zdaniowym. Język formalny logiki powinności i dobra, którym dalej będziemy się posługiwać, będzie także zawierał: modalny operator dobra (elementarną ocenę „dobrze, że jest tak a tak” oznaczamy za pomocą „Dp”), symbole zdaniowe $p, q, r \ldots$, tradycyjne spójniki logiczne negacji, koniunkcji, alternatywy, implikacji i równoważności oraz nawiasy jako symbole pomocnicze. Litery $\alpha, \beta, \gamma \ldots$ będą zastępować dowolnie ustalone poprawnie zbudowane formuly tego języka33. Możemy teraz wyrazić definicję dobra w języku formalnym za pomocą następującego skrótu definicyjnego:

$$
\mathrm{D} \alpha \equiv \mathrm{df} \alpha \wedge \mathrm{O} \alpha .
$$

Choć Elzenberg pojęcie powinności uczynił pojęciem pierwotnym swojego systemu aksjologii formalnej, to jednak opatrzył je dość znacznym komentarzem. Komentarz ten posłuży nam jako punkt wyjścia charakterystyki warunku prawdziwości dla podstawowej normy.

Powinność jest związana z wolą. Z jednej strony wszelka świadomość powinności stanowi dla woli motyw do działania, ponieważ:

ilekroć stwierdzam, że powinno być tak a tak i stwierdzam jednocześnie, że realizacja tego stanu rzeczy jest zależna od mojej woli, to odczuwam pewien nacisk, siłę popychającą mnie do tego, bym starał się „powinny” stan rzeczy zrealizować (Elzenberg 2002a: 162).

Z drugiej strony powinność jest też wyrazem woli, ponieważ:

\footnotetext{
$3 \mathrm{~W}$ dalszej części z literami $p, q, r_{\ldots} .$. jak i $\alpha, \beta, \gamma \ldots$ będzie związana pewna dwuznaczność, gdyż będą one oznaczały zarówno pewne sądy, jak i ich korelaty przedmiotowe, czyli - w przypadku liter zdaniowych - stany rzeczy, a w przypadku $\alpha, \beta, \gamma \ldots$ sytuacje. Przyjmujemy, że stany rzeczy to sytuacje proste, czyli takie, które mogą być przedmiotem przedstawień. Dalej, zamiast mówić za Elzenbergiem o powinnych lub dobrych stanach rzeczy, będziemy mówić - ogólniej - o powinnych i dobrych sytuacjach.
} 
„powinno” znaczy „ja chcę, żeby A”. Ale „chcę” nie chceniem zwykłym, empirycznym tylko jakimś innym, które nawet może znaleźć się w kolizji z tamtym. Ma to być jakieś chcenie wolne, niezależne, autonomiczne (niedeterminowane przez naturę, tzn. niezależne od skłonności), bez motywu, czyste sic volo, wola czysta (Elzenberg 2002a: 165).

Dlatego Elzenberg za powinne proponuje uznać te stany rzeczy, których chciałby ktoś obdarzony taką specyficzną wolą - wolą metaempiryczną. Taka wola nie ulega motywom o charakterze emocjonalno-popędowym. Kieruje się czystymi racjami i dlatego można ją też nazwać wolą nieheteronomiczną lub autonomiczną. Oczywiście naszej woli empirycznej daleko do woli autonomicznej, bo często ponad to, co powinne, stawiamy to, co dla nas jedynie przyjemne lub korzystne. Niemniej, choć wola metaempiryczna jest czystym konstruktem myślowym, to jednak stanowi pewien wzorzec, do którego chcemy upodabniać naszą wolę, kiedy pytamy, co być powinno4. Wola metaempiryczna jest wskazówką, jak obierać cele, by wybić się w chceniu na niezależność.

Powinność jest kierunkiem, w którym podąża wola autonomiczna. O kierunkowości takiej woli Elzenberg pisze tak:

przypuśćmy, że sobie mówię „chcę stanu rzeczy A” albo, że „moim obowiązkiem jest stworzyć stan rzeczy A". W obu wypadkach:

a) intendujemy ku przyszłości (mamy postawę prospektywną);

b) przedstawiamy sobie pewien określony stan rzeczy jako przyszły i działanie zmierzające do jego urzeczywistnienia [...];

c) odnosimy się jakoś pozytywnie do tego przyszłego stanu rzeczy i do zmierzającego ku niemu działania (Elzenberg 2002d: 302-303).

Określając więc, co jest powinne, nakierowujemy się na stan rzeczy, który: a) nie zachodzi, nie jest faktem; b) może być, ale nie musi; c) jego zajście jest czymś pozytywnym; lepiej żeby zaszedł, aniżeli miałoby go nie być. Powinność jest zatem związana z tym, co dopiero ma być, ale co nie jest ani niemożliwe, ani konieczne; ponadto z tym, co preferuje wola metaempiryczna, czyli co, z punktu widzenia świata jako całości, lepiej gdy zachodzi, niż gdy nie zachodzi.

Te intuicje związane z powinnością posłużą dalej do sformułowania semantycznego warunku prawdziwości norm o postaci „powinno być tak a tak”. Ponieważ wybieranie, preferowanie czy rekomendowanie, a więc racjonalne działania związane z powinnością, zakładają jakieś alternatywne możliwości

\footnotetext{
4 Warto zauważyć, że podobne konstrukcje myślowe podawane w celu scharakteryzowania pojęć etycznych pojawiały się również gdzie indziej w dwudziestowiecznej filozofii moralnej. Jako przykład może posłużyć choćby teoria idealnego obserwatora czy też metoda kontrolowanej postawy (Brandt 1996: 297-298, 427). Według tych teorii, aby ustalić powinności, należy swoją postawę upodobnić do postawy idealnego obserwatora albo zweryfikować metodą kontrolowanej postawy.
} 
działania, to najwygodniej będzie rozpatrywać warunki prawdziwości norm w semantyce światów możliwych. Niech modelem języka logiki powinności i dobra będzie czwórka uporządkowana:

$$
\mathrm{M}=<\mathrm{W}, \mathrm{R}, \text { Lep, } \mathrm{V}>\text {, }
$$

gdzie $\mathrm{W}$ jest niepustym zbiorem światów możliwych, natomiast $\mathrm{R}$ relacją osiągalności między tymi światami. Napis „R $(u, w)$ ” czytamy „świat $w$ jest alternatywny względem świata $u$ (świat $w$ jest osiągalny z $u$ )” albo inaczej „,w jest możliwym wyjściem $\mathrm{z}$ okoliczności $u$ ”. O relacji $\mathrm{R}$ zakładamy, że jest zwrotna, tzn. dla każdego $u \in \mathrm{W}, \mathrm{R}(u, u)$. Z kolei Lep jest trójelementową relacją zadaną na elementach zbioru $W$. Jest to relacja relatywnej preferencji między światami ${ }^{\text {. Napis } ~ „ L e p ~}(w, t)$ ” czytamy „z punktu widzenia świata $u$ lepiej kiedy $w$ niż $t$ ". Zakładamy, że relacja Lep ma następujące własności formalne. Dla dowolnego $u, v, w, t$ :

przeciwzwrotność: nieprawda, że $\operatorname{Lep}_{u}(w, w)$;

$$
\text { asymetryczność: jeśli } \operatorname{Lep}_{u}(w, t) \text {, to nieprawda, że } \operatorname{Lep}_{u}(t, w) \text {; }
$$

$$
\text { przechodniość: jeśli } \operatorname{Lep}_{u}(w, t) \mathrm{i} \mathrm{Lep}_{u}(t, v) \text {, to } \operatorname{Lep}_{u}(w, v) \text {. }
$$

Ze względu na relację Lep semantykę tę dalej będziemy nazywać semantyką relatywnej preferencji.

Pojęcie prawdziwości dowolnej formuły $\gamma$ języka logiki powinności i dobra $\mathrm{w}$ modelu $\mathrm{M}$, świecie $u$, w skrócie $(\mathrm{M}, u) \vDash \gamma$, definiujemy indukcyjnie ze względu na możliwą budowę formuły $\gamma$. Dla formuł niepoprzedzonych operatorem powinności definicja przybiera standardową postać - na przykład dla liter zdaniowych, negacji i implikacji mamy:

$$
\begin{aligned}
& (\mathrm{M}, u) \vDash p \text { wtw, gdy } u \in \mathrm{V}(p), \\
& (\mathrm{M}, u) \vDash \sim \alpha \text { wtw, gdy nieprawda, że }(\mathrm{M}, u) \vDash \alpha, \\
& (\mathrm{M}, u) \vDash \alpha \rightarrow \beta \text { wtw, gdy jeśli }(\mathrm{M}, u) \vDash \alpha, \text { to }(\mathrm{M}, u) \vDash \beta
\end{aligned}
$$

Najciekawszy jest przypadek warunku prawdziwości dla normy o postaci $\mathrm{O} \alpha$. Zanim do niego przejdziemy, przyjmijmy pewien skrót definicyjny:

$$
\operatorname{Alt}_{u}(\alpha)=\{w \in \mathrm{W}: \mathrm{R}(u, w) \mathrm{i}(\mathrm{M}, w) \vDash \alpha\} .
$$

$\operatorname{Alt}_{u}(\alpha)$ to zbiór wszystkich następstw świata $u$, w których zachodzi $\alpha$, czyli, mówiąc najprościej, zbiór $\alpha$-alternatyw świata $u$. Teraz

\footnotetext{
5 Przedstawiona tu semantyka inspirowana jest ujęciem zaproponowanym przez Franka Jacksona (1985) i rozwijanym przez Lou Goble'a (1990a, 1990b, 1993).
} 


$$
\begin{aligned}
& (\mathrm{M}, u) \vDash \mathrm{O} \alpha \mathrm{wtw}, \operatorname{gdy}_{\operatorname{Alt}_{u}}(\alpha) \neq \varnothing \mathrm{i} \operatorname{Alt}_{u}(\sim \alpha) \neq \varnothing \mathrm{i} \text { dla każdego } \\
& w, t \text { jeśli } w \in \operatorname{Alt}_{u}(\alpha) \text { i } t \in \operatorname{Alt}_{u}(\sim \alpha), \text { to } \operatorname{Lep}_{u}(w, t) .
\end{aligned}
$$

Oznacza to, że sytuacja $\alpha$ jest powinna w świecie $u$ modelu M wtedy i tylko wtedy, gdy dowolna możliwa $\alpha$-alternatywa dla świata $u$ jest lepsza od dowolnej możliwej $\sim \alpha$-alternatywy świata $u$. Na przykład z punktu widzenia naszego świata powinno być tak, że ludzie sobie wzajemnie pomagają, bo choć mogliby sobie wzajemnie zarówno pomagać, jak i nie pomagać, to jednak lepiej, gdy sobie pomagają.

Zilustrujmy intuicje stojące za tym warunkiem. Widzimy wypadek samochodowy. Rozum podpowiada możliwe dalsze przebiegi wydarzeń: w jednych pomaga się poszkodowanym, w innych nie. Wola empiryczna, którą staramy się upodobnić do woli autonomicznej, preferuje te możliwe następstwa, w których pomaga się poszkodowanym. Tak więc uznajemy, że w tych okolicznościach powinno się pomóc poszkodowanym. Widać tu warunki (a-c) z przywołanego fragmentu rękopisów Elzenberga (2002d). Szukając powinności, spoglądamy na możliwe następstwa, na to, co może być, ale nie musi, i pytamy, co wolimy, bez oglądania się na własny interes i własną przyjemność. Tym samym upodabniamy swoją wolę empiryczną do woli autonomicznej.

Podamy teraz warunki prawdziwości dla innego rodzaju norm deontycznych. Normy te będą odpowiadały następującemu podziałowi sytuacji ze względu na klasyfikację deontyczną.

Dopuszczalne

\begin{tabular}{|c|c|c|}
\hline Powinne & Neutralne & Przeciwpowinne \\
$\underbrace{}_{\text {Niepowinne }}$
\end{tabular}

Jak widać, sytuacje dzielimy na powinne, neutralne i przeciwpowinne. Przy czym powinne i neutralne to sytuacje dopuszczalne deontycznie ${ }^{6}$, natomiast neutralne i przeciwpowinne to sytuacje niepowinne deontycznie.

Normę wyrażającą przeciwpowinność sytuacji $\alpha$ oznaczmy za pomocą „W $\alpha$ ”; warunek prawdziwości w świecie $u$ modelu M przybiera wówczas postać:

\footnotetext{
${ }^{6}$ Przyjmujemy ten termin za Markiem Magdziakiem (1998: 148). Stig Kanger do tego rodzaju sytuacji proponuje stosować termin „słuszność” (right), a dla sytuacji, które my określamy za Magdziakiem jako przeciwpowinne, termin „błędność/niesłuszność” (wrong) (Kanger 1971: 39). Terminologia Kangera jest już dość mocno osadzona w dyskursie związanym z kwalifikacją etyczną czynów, dlatego mogłaby razić sztucznością, gdyby była również stosowana do sytuacji.
} 
$(\mathrm{M}, u) \vDash \mathrm{W} \alpha$ wtw, $\operatorname{gdy}_{\operatorname{Alt}}(\alpha) \neq \varnothing \mathrm{i} \operatorname{Alt}_{u}(\sim \alpha) \neq \varnothing \mathrm{i}$ dla każdego $w$, $t$ jeśli $w \in \operatorname{Alt}_{u}(\alpha)$ i $t \in \operatorname{Alt}_{u}(\sim \alpha)$, to $\operatorname{Lep}_{u}(t, w)$.

Zatem w świecie $u$ przeciwpowinna jest sytuacja $\alpha$ wtedy i tylko wtedy, gdy każda możliwa $\sim \alpha$-alternatywa tego świata jest lepsza od dowolnej jego $\alpha$-alternatywy. Przeciwpowinne są więc te sytuacje, które lepiej, żeby nie były, niż żeby były.

Normę wyrażającą dopuszczalność sytuacji $\alpha$ będziemy oznaczać za pomocą „R $\alpha$ ”. Warunek prawdziwości normy R $\alpha$ w dowolnym świecie $u$ modelu M przybiera postać:

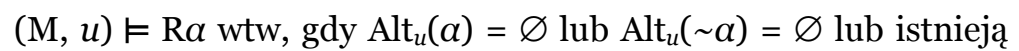
$w, t$ takie, że $w \in \operatorname{Alt}_{u}(\alpha), t \in \operatorname{Alt}_{u}(\sim \alpha)$ i nieprawda, że $\operatorname{Lep}_{u}(t, w)$.

Sytuacja $\alpha$ jest dopuszczalna w świecie $u$ modelu M wtedy i tylko wtedy, gdy świat $u$ nie ma $\alpha$-alternatyw albo $\sim \alpha$-alternatyw lub istnieje pewna jego $\alpha$-alternatywa, dla której nieprawda, że nie jest lepsza (która nie jest gorsza) od pewnej jego $\sim \alpha$-alternatywy. Dopuszczalne są więc te sytuacje, które są albo konieczne bądź niemożliwe logicznie, albo w przypadku których nie zawsze jest gorzej, gdy są, niż gdy nie są.

Dla neutralności rezerwujemy operator „P”. Warunek prawdziwości w świecie $u$ modelu M normy $\mathrm{P} \alpha$ przybiera postać:

$(\mathrm{M}, u) \vDash \mathrm{P} \alpha$ wtw, $\operatorname{gdy}^{\operatorname{Alt}_{\mathrm{u}}}(\alpha)=\varnothing \operatorname{lub}^{\mathrm{Alt}}(\sim \alpha)=\varnothing \operatorname{lub}$ istnieją $w$, $t$ takie, że $w \in \operatorname{Alt}_{u}(\alpha), t \in \operatorname{Alt}_{u}(\sim \alpha)$ i nieprawda, że $\operatorname{Lep}_{u}(t, w)$, $\mathrm{i}$ istnieją $v, s$ takie, że $v \in \operatorname{Alt}_{u}(\alpha), s \in \operatorname{Alt}_{u}(\sim \alpha)$ i nieprawda, że $\operatorname{Lep}_{u}(v, s)$.

Sytuacja $\alpha$ jest neutralna w świecie $u$ modelu M wtedy i tylko wtedy, gdy świat ten nie ma $\alpha$-alternatyw albo $\sim \alpha$-alternatyw lub gdy istnieje dla niego pewna $\alpha$-alternatywa, która nie jest gorsza od pewnej jego $\sim \alpha$-alternatywy, i istnieje pewna jego $\sim \alpha$-alternatywa, która nie jest gorsza od pewnej jego $\alpha$-alternatywy. Neutralne są więc te sytuacje, które nie są ani powinne, ani przeciwpowinne.

Teraz kategoria niepowinnych sytuacji (normę oznaczamy $\mathrm{N} \alpha$ ). Dla dowolnego świata $u$ modelu M:

$(\mathrm{M}, u) \vDash \mathrm{N} \alpha$ wtw, $\operatorname{gdy}_{\operatorname{Alt}}(\alpha)=\varnothing \operatorname{lub}_{\mathrm{Alt}}(\sim \alpha)=\varnothing$ lub istnieją $w, t$ takie, że $w \in \operatorname{Alt}_{u}(\alpha), t \in \operatorname{Alt}_{u}(\sim \alpha)$ i nieprawda, że $\operatorname{Lep}_{u}(w, t)$.

Sytuacja $\alpha$ jest niepowinna w świecie $u$ modelu M wtedy i tylko wtedy, gdy świat $u$ nie ma $\alpha$-alternatyw albo $\sim \alpha$-alternatyw lub istnieje pewna jego $\sim \alpha$-alternatywa, która nie jest gorsza (jest lepsza) od pewnej jego $\alpha$-alternatywy.

Widać, że jedynie sytuacje przygodne mogą być powinne lub przeciwpowinne. Gdyby bowiem dla dowolnie ustalonej sytuacji $\alpha$ i okoliczności $u$ przyjąć 
$\operatorname{Alt}_{u}(\sim \alpha)=\varnothing$, to na mocy pustospełnionego warunku każda $\alpha$-alternatywa świata $u$ byłaby lepsza od dowolnej $\sim \alpha$-alternatywy tego świata (nie byłoby możliwe znalezienie $\sim \alpha$-alternatywy lepszej od $\alpha$-alternatywy) oraz, równocześnie, każda $\sim \alpha$-alternatywa świata $u$, na mocy pustospełnionego warunku, byłaby lepsza od dowolnej jego $\alpha$-alternatywy (nie byłoby możliwe znalezienie $\sim \alpha$-alternatywy gorszej od $\alpha$-alternatywy). Dlatego konieczna logicznie sytuacja $\alpha$ byłaby zarazem powinna i przeciwpowinna, co przeczy naszym elementarnym intuicjom związanym z rekomendacją (analogicznie dla sytuacji niemożliwej logicznie). Tak więc sytuacje konieczne i niemożliwe, z punktu widzenia kwalifikacji deontycznej, są neutralne, a przez to niepowinne i dopuszczalne zarazem7.

Przedstawione warunki prawdziwości pozwalają dostrzec analogię między modalnościami deontycznymi a modalnościami kwantyfikatorowymi. Na przykład z powinnością wiąże się duży kwantyfikator, ponieważ sytuacja $\alpha$ jest powinna w danym świecie, jeśli każda $\alpha$-alternatywa tego świata jest lepsza od dowolnej $\sim \alpha$-alternatywy tego świata, natomiast z dopuszczalnością jest związany mały kwantyfikator, ponieważ sytuacja $\alpha$ jest dopuszczalna w danym świecie, o ile istnieje pewna $\alpha$-alternatywa tego świata lepsza od pewnej jego $\sim \alpha$-alternatywy. Dlatego, jak definiujemy mały kwantyfikator za pomocą dużego kwantyfikatora ( $\exists \mathrm{x}: \alpha \equiv \mathrm{df} \sim \forall \mathrm{x}: \sim \alpha$ ), tak możemy zdefiniować dopuszczalność za pomocą pojęcia powinności ( $\mathrm{R} \alpha \equiv \mathrm{df} \sim \mathrm{O} \sim \alpha$ ). Dalsze podobieństwa pokazuje tabela (strzałka oznacza kierunek przebiegu relacji Lep):

\begin{tabular}{|c|c|c|c|c|}
\hline $\begin{array}{l}\text { Powinny } \\
\mathrm{O} \alpha\end{array}$ & $\begin{array}{c}\text { Dopuszczalny } \\
\sim 0 \sim \alpha\end{array}$ & $\begin{array}{c}\text { Przeciwpowinny } \\
\text { O } \sim \alpha\end{array}$ & $\begin{array}{l}\text { Niepowinny } \\
\quad \sim \mathrm{O} \alpha\end{array}$ & $\begin{array}{l}\text { Neutralny } \\
\sim \mathrm{O} \sim \alpha \wedge \sim \mathrm{O} \alpha\end{array}$ \\
\hline & & $\widehat{\operatorname{Alt}_{u}(\alpha)}$ & & \\
\hline $\begin{array}{l}\text { Każdy } \\
\forall \mathrm{x}: \alpha\end{array}$ & $\begin{array}{l}\text { Pewien } \\
\sim \forall \mathrm{x}: \sim \alpha\end{array}$ & $\begin{array}{l}\text { Żaden } \\
\forall \mathrm{x}: \sim \alpha\end{array}$ & $\begin{array}{l}\text { Nie każdy } \\
\quad \sim \forall \mathrm{x}: \alpha\end{array}$ & $\begin{array}{l}\text { Pewien tak i pewien nie } \\
\quad \sim \forall \mathrm{x}: \sim \alpha \wedge \sim \forall \mathrm{x}: \alpha\end{array}$ \\
\hline
\end{tabular}

Zachodzenie analogii na poziomie związków definicyjnych między modalnościami deontycznymi a kwantyfikatorowymi podpowiada, że można zbu-

7 Nie należy tego faktu łączyć z tzw. zasadą Kanta, że „powinność implikuje możność”. Zasada ta dotyczy raczej powinności w sensie obowiązku i ustanawia warunek możliwości działania dla kogoś, kto miałby podlegać obowiązkowi. 
dować sześciokąt opozycji logicznych obrazujący wzajemne związki logiczne między podstawowymi normami w taki sam sposób, jak robi się to dla zobrazowania związków między zdaniami kategorycznymi (Rönnedal 2017: 162).

Możemy teraz zapytać, jakie formuły logiki powinności są prawdziwe w semantyce relatywnej preferencji. Na pewno obowiązują wszystkie związki logiczne sześciokąta opozycji deontycznych, albowiem dla dowolnego modelu $\mathrm{M}$ i dowolnego świata $u$ prawdziwe są formuły:

(KP1)

$$
\sim(\mathrm{O} \alpha \wedge \mathrm{O} \sim \alpha), \text { czyli } \sim(\mathrm{O} \alpha \wedge \mathrm{W} \alpha),
$$

$$
(\mathrm{O} \alpha \rightarrow \sim \mathrm{O} \sim \alpha \text { ), czyli } \mathrm{O} \alpha \rightarrow \mathrm{R} \alpha \text {, }
$$

$$
\sim \mathrm{O} \sim \alpha \vee \sim \mathrm{O} \alpha \text {, czyli } \mathrm{R} \alpha \vee \mathrm{N} \alpha \text {, }
$$

$$
\mathrm{O} \sim \alpha \rightarrow \sim \mathrm{O} \alpha \text {, czyli W } \alpha \rightarrow \mathrm{N} \alpha \text {. }
$$

Prawdziwość formuł (KP1-KP4) wynika z tego, że relacja Lep jest asymetryczna. Dla przykładu pokażemy dowód, że dla dowolnego $\mathrm{M}$ i dowolnego $u$ zachodzi $(\mathrm{M}, u) \vDash \sim(\mathrm{O} \alpha \wedge \mathrm{O} \sim \alpha)$. Załóżmy nie wprost: $(\mathrm{M}, u) \vDash(\mathrm{O} \alpha \wedge \mathrm{O} \sim \alpha)$. Zatem $(\mathrm{M}, u) \vDash \mathrm{O} \alpha$ oraz $(\mathrm{M}, u) \vDash \mathrm{O} \sim \alpha$. Z definicji spełniania wnosimy, że $\operatorname{Alt}_{\mathrm{u}}(\alpha) \neq \varnothing$ i $\operatorname{Alt}_{\mathrm{u}}(\sim \alpha) \neq \varnothing$, i dla każdego $w$, $t$ jeśli $w \in \operatorname{Alt}_{u}(\alpha)$ i $t \in \operatorname{Alt}_{u}(\sim \alpha)$, to $\operatorname{Lep}_{u}(w, t)$, oraz dla każdego $w, t$ jeśli $w \in \operatorname{Alt}_{u}(\alpha)$ i $t \in \operatorname{Alt}_{u}(\sim \alpha)$, to $\operatorname{Lep}_{u}(t, w)$. To jednak niemożliwe, ponieważ relacja Lep jest relacją asymetryczną, więc jeśli $\operatorname{Lep}_{u}(w, t)$, to nie może być tak, aby $\operatorname{Lep}_{u}(t, w)$.

Szczególnie ciekawa jest odpowiedź na pytanie, czy system logiki powinności „wydobyty” przez Wolniewicza z pism Elzenberga będzie spełniony w semantyce relatywnej preferencji, która się również odwołuje do intuicji Elzenberga. Przypomnijmy, że według Wolniewicza system obecny implicite w zapiskach Elzenberga jest nieznacznie mocniejszy od standardowej logiki powinności i opiera się na zasadach ${ }^{8}$ :

$$
\begin{array}{ll}
\text { (SE1) } & \mathrm{O} \alpha \wedge \sim \diamond(\alpha \wedge \beta) \rightarrow \mathrm{O} \sim \beta, \\
\text { (SE2) } & \sim(\mathrm{O} \alpha \wedge \mathrm{O} \sim \alpha), \\
\text { (SE3) } & \mathrm{O} \alpha \rightarrow \diamond \alpha, \\
\text { (SE4) } & \mathrm{O} \alpha \wedge \mathrm{O} \beta \equiv \mathrm{O}(\alpha \wedge \beta) .
\end{array}
$$

Okazuje się, że w przedstawionej semantyce jest spełniona zasada deontycznej niesprzeczności (SE2), zasada Kanta (SE3) oraz - w słabszej postaci, tzn. $\mathrm{O} \alpha \wedge \sim \diamond(\alpha \wedge \beta) \rightarrow \sim \mathrm{O} \beta$ - zasada Elzenberga (SE1). Nie jest jedynie spełniona zasada (SE4), co jak się wydaje, nie jest przypadkowe, biorąc pod uwagę, że trzy pierwsze zasady mają dużą doniosłość filozoficzną, natomiast ostatnia

\footnotetext{
${ }^{8} \mathrm{~W}$ formułach symbol $\diamond$ oznacza aletyczny operator możliwości.
} 
poucza jedynie, jak operator powinności zachowuje się względem koniunkcji. Fakt takiego rozkładu formuł spełnionych w semantyce relatywnej preferencji potwierdza przypuszczenie, że Elzenberg był przede wszystkim nastawiony na filozoficzne analizy pojęć moralnych i daleko mu było do poszukiwania aż tak ogólnych form myślenia o powinności, które kilkadziesiąt lat później wtłoczyły logikę powinności w zgubną - jak twierdzą niektórzy (Goble 1990a: 181-183, Mothersill 1996: 70) - analogię z logiką aletyczną i innymi logikami modalnymi.

Dodajmy, że skoro semantyka relatywnej preferencji nie spełnia (SE4), to nie może być również semantyką dla systemu standardowego logiki deontycznej. Nie stanowi to jednak większego problemu, zważywszy na to, jak wiele paradoksalnych zasad należy do zbioru twierdzeń tego systemu.

\section{DOBRO}

Elzenberg nie był w pełni zadowolony z podanej przez siebie definicji wartości rzeczy jako tego, co jest takie, jakie być powinno. Dręczyła go wątpliwość, czy powinność bycia takim to a takim może pozostawać bez racji. $\mathrm{W}$ wykładach toruńskich pisal:

chcąc zatem ratować swoją definicję muszę [...] zgodzić się, że powinność jest bez żadnej racji. Taka zupełna irracjonalność powinności zupełnie mi nie odpowiada [...]; moje intuicje najsilniej przemawiają za czymś, co uzasadnia powinność, i co jest oczywiście rodzajem wartości, chociaż nie wartości rzeczy” (Elzenberg 2002c: 233).

W związku z tym Elzenberg rozważa inną możliwość - „postawienia na głowie” swojego systemu, tzn. zdefiniowania powinności przez odwołanie do pojęcia wartości jako terminu pierwotnego systemu. Pisze:

otóż w naszym przypadku myśl o „postawieniu na głowie” o tyle się nasuwa jako kusząca, że nasza definicja (wartości przez powinność) [...] tylko bardzo częściowo zadowala pod względem intuicyjnym [...]; nie jest bowiem zgodne $\mathrm{z}$ intuicją by, jak to $\mathrm{z}$ tamtej definicji wynikało, powinność „spadała z nieba”, wydaje nam się, że wynika ona z wartości (Elzenberg 2002c: 247).

Elzenberg podaje kilka możliwych formuł definicyjnych. Zwrot „powinno być tak a tak” mógłby być równoważny zwrotowi „jeżeli coś jest takie a takie, to jest bardziej wartościowe, niż gdyby nie było" (Elzenberg 2002a: 162). Albo, $\mathrm{w}$ trochę innym sformułowaniu, ,jeżeli tak a tak, to świat jest bardziej wartościowy, niż gdyby nie tak a tak" (Elzenberg 2002a: 162-163). Co ciekawe, gdzie indziej Elzenberg uznał sformułowanie „dzięki temu, że tak a tak, świat jako całość jest bardziej wartościowy” za interpretację wyrażenia o postaci 
„dobrze jest, że tak a tak” (Elzenberg 2002a: 144), zawierającego operator modalny „dobrze, że...”. Dlatego definicję powinności możemy teraz zapisać następująco:

$$
\mathrm{O} \alpha \equiv \mathrm{df} \alpha \rightarrow \mathrm{D} \alpha .
$$

Tak jak wcześniej zwrócimy się do semantycznej interpretacji podstawowego wyrażenia należącego do definicji, tym razem będzie to interpretacja oceny o postaci $\mathrm{D} p$. Z przytoczonych sformułowań Elzenberga oddających sens oceny „dobrze, że jest tak a tak” wnosimy, że warunek prawdziwości powinien uwzględniać kilka intuicji podobnych do tych, które występowały w odniesieniu do normy powinności. Dobry stan rzeczy to taki, który: a) jest (jest faktem); b) mógłby nie być (nie jest konieczny); c) lepiej, że jest, niż gdyby miało go nie być (jest preferowany z punktu widzenia świata jako całości, a więc przez wolę metaempiryczną).

Korzystając z semantyki relatywnej preferencji, dla dowolnego modelu M i świata $u$ możemy teraz określić warunek prawdziwości oceny $\mathrm{D} \alpha$ następująco:

$$
\begin{aligned}
& (\mathrm{M}, u) \vDash \operatorname{D} \alpha \text { wtw, } \operatorname{gdy}(\mathrm{M}, u) \vDash \alpha \text { i } \operatorname{Alt}_{u}(\sim \alpha) \neq \varnothing \text { i dla każdego } t \text { jeśli } \\
& t \in \operatorname{Alt}_{u}(\sim \alpha), \text { to } \operatorname{Lep}_{u}(u, t),
\end{aligned}
$$

co czytamy: sytuacja $\alpha$ jest dobra w świecie $u$ modelu M wtedy i tylko wtedy, gdy $\alpha$ zachodzi w świecie $u$, ale nie musi, a przy tym lepiej, że $\alpha$ zachodzi w świecie $u$, niż gdyby miała zajść dowolna $\sim \alpha$-alternatywa dla świata $u$. Na przykład z punktu widzenia naszego świata dobrze, że ludzie sobie wzajemnie pomagają, bo choć mogliby sobie wzajemnie nie pomagać, to jednak lepiej, że sobie pomagają.

Możemy posługiwać się tą samą semantyką co dla powinności, ponieważ dla obu pojęć (dobra i powinności) ważny jest ten sam fundament: rozważanie światów możliwych, czyli inaczej sposobów działania, jako że światy możliwe można rozumieć jako skutki działań. $\mathrm{W}$ odniesieniu do powinności rozważamy światy, które mogą zajść, czyli mogą być skutkiem wolnych działań. W odniesieniu do dobra poruszamy się między faktami a kontrfaktycznymi możliwościami. Dla obu pojęć ważny jest również akt preferencji woli metaempirycznej - woli, która przedkłada pewne światy nad inne jako lepsze, nie oglądając się na to, co subiektywne, ponieważ kieruje się jedynie czystymi racjami.

Podamy teraz warunki prawdziwości dla kolejnego rodzaju ocen moralnych. Będą one odpowiadały następującemu podziałowi sytuacji ze względu na klasyfikację aksjologiczną. 
Akceptowalne

\begin{tabular}{|c|c|c|}
\hline Dobre & Obojętne & Zle \\
\hline
\end{tabular}

Sytuacje mogą być dobre, złe lub obojętne moralnie. Dobre i obojętne sytuacje nazywamy akceptowalnymi, natomiast obojętne i złe - niedobrymi.

Dla zła (normę oznaczamy $Z \alpha$ ), przy dowolnie ustalonym świecie $u$ i modelu M, formułujemy definicję:

$$
\begin{aligned}
& (\mathrm{M}, u) \vDash Z \alpha \text { wtw, gdy }(\mathrm{M}, u) \vDash \alpha \text { i } \operatorname{Alt}_{\mathrm{u}}(\sim \alpha) \neq \varnothing \text { i dla każdego } t \text { jeśli } \\
& t \in \operatorname{Alt}_{u}(\sim \alpha), \text { to } \operatorname{Lep}_{u}(t, u) .
\end{aligned}
$$

Sytuacja $\alpha$ jest zła w świecie $u$ modelu M wtedy i tylko wtedy, gdy $\alpha$ zachodzi $\mathrm{w} u$, choć mogłaby nie zachodzić, i lepiej gdyby zaszła dowolna $\sim \alpha$-alternatywa dla świata $u$. Sytuacja zła to taka, która choć jest, to ze wszech miar lepiej, gdyby jej nie było.

Dla normy wyrażającej akceptowalność sytuacji $\alpha$ (symbolicznie A $\alpha$ ), przy dowolnie ustalonym świecie $u$ i modelu M, warunek prawdziwości przybiera następującą postać:

$(\mathrm{M}, u) \vDash \mathrm{A} \alpha$ wtw, gdy $(\mathrm{M}, u) \vDash \alpha \mathrm{i} \mathrm{Alt}_{u}(\sim \alpha)=\varnothing$ bądź istnieje $t$ takie, że $t \in \operatorname{Alt}_{u}(\sim \alpha)$ i nieprawda, że $\operatorname{Lep}_{u}(t, u)$.

Oznacza to, że sytuacja $\alpha$ jest akceptowalna w świecie $u$ modelu M wtedy i tylko wtedy, gdy $\alpha$ zachodzi w $u$ i jest logicznie konieczna albo dla pewnej $\sim \alpha$-alternatywy świata $u$ jest lepiej, że $\alpha$ zachodzi w $u$. Sytuacja jest więc akceptowalna, gdy nie jest zła.

Definicja prawdziwości oceny „niedobrze, że $\alpha$ ” (symbolicznie E $\alpha$ ) dla dowolnego świata $u$ i modelu M to:

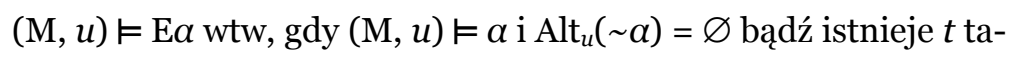$$
\text { kie, że } t \in \operatorname{Alt}_{u}(\sim \alpha) \text { i } \operatorname{Lep}_{u}(t, u) \text {. }
$$

Tak więc sytuacja $\alpha$ jest niedobra w świecie $u$ modelu M wtedy i tylko wtedy, gdy $\alpha$ zachodzi w $u$ i jest logicznie konieczna albo dla pewnej $\sim \alpha$-alternatywy dla świata $u$ jest gorzej, że $\alpha$ zachodzi w $u$.

I wreszcie definicja warunku prawdziwości oceny „obojętnie, że $\alpha$ ” (symbolicznie I $\alpha$ ), dla dowolnego świata $u$ i modelu M: 
$(\mathrm{M}, u) \vDash \mathrm{I} \alpha$ wtw, gdy $(\mathrm{M}, u) \vDash \alpha$ i $\operatorname{Alt}_{\mathrm{u}}(\sim \alpha)=\varnothing$ bądź istnieje $t$ takie, że $t \in \operatorname{Alt}_{u}(\sim \alpha)$ i nieprawda, że $\operatorname{Lep}_{u}(t, u)$, i istnieje $v$ takie, że $v \in \operatorname{Alt}_{u}(\sim \alpha)$ i nieprawda, że $\operatorname{Lep}_{u}(u, v)$.

Sytuacja $\alpha$ jest obojętna w świecie $u$ modelu M wtedy i tylko wtedy, gdy $\alpha$ zachodzi $\mathrm{w} u$ i jest logicznie konieczna albo dla pewnej $\sim \alpha$-alternatywy dla świata $u$ jest lepiej, że $\alpha$ zachodzi w $u$ i dla pewnej $\sim \alpha$-alternatywy dla świata $u$ jest gorzej, że $\alpha$ zachodzi w $u$.

Jak widać, zgodnie z przedstawionymi definicjami tylko sytuacje przygodne oraz konieczne podlegają kwalifikacji aksjologicznej. Przy czym każda sytuacja konieczna logicznie jest obojętna etycznie, przez co jest niedobra, choć etycznie akceptowalna.

Również operator dobra i pozostałe operatory zachowują się podobnie do kwantyfikatorów. W zależności od tego, czy każda, pewna, żadna, nie każda, pewna tak, a pewna nie $\sim \alpha$-alternatywa jest gorsza od $u$, gdzie zachodzi $\alpha$, mamy kolejne kwalifikacje aksjologiczne dla $\alpha$ : dobre, akceptowalne, złe, niedobre i obojętne. Kolejne elementy tej analogii obrazuje tabela.

\begin{tabular}{|c|c|c|c|c|}
\hline $\begin{array}{c}\text { Dobry } \\
\mathrm{D} \alpha\end{array}$ & $\begin{array}{c}\text { Akceptowalny } \\
\mathrm{A} \alpha\end{array}$ & $\begin{array}{c}\text { Zty } \\
\mathrm{Z} \alpha\end{array}$ & $\begin{array}{c}\text { Niedobry } \\
\mathrm{E} \alpha\end{array}$ & $\begin{array}{c}\text { Obojętny } \\
\mathrm{I} \alpha\end{array}$ \\
\hline \multicolumn{5}{|c|}{$u$} \\
\hline \multicolumn{5}{|c|}{$\operatorname{Alt}_{u}(\sim \alpha)$} \\
\hline Każdy & Pewien & Żaden & Nie każdy & Pewien tak i pewien nie \\
\hline
\end{tabular}

Analogia między modalnościami aksjologicznymi i kwantyfikatorowymi załamuje się na poziomie związków definicyjnych. $Z$ uwagi na założenia semantyczne nie obowiązują równoważności o postaci $Z \alpha \equiv \mathrm{D} \sim \alpha$, ponieważ warunki prawdziwości obu członów wymagałyby, aby zarazem $(\mathrm{M}, u) \vDash \alpha$ oraz $(\mathrm{M}, u) \vDash \sim \alpha$, co jest niemożliwe. Nawiasem mówiąc, jest to również zgodne z przekonaniami Elzenberga, który tak pisze o złu:

zakłada się, że termin „wartość ujemna” znaczy [...] tyle co „taki, jaki powinien nie być”

(Elzenberg 2002b: 171).

W naszym języku formalnym możemy to zapisać:

$$
\mathrm{Z} \alpha \equiv{ }^{\mathrm{df}} \alpha \wedge \mathrm{O} \sim \alpha .
$$


Pamiętając, że dla dobra Elzenberg podawał podobną definicję: $\mathrm{D} \alpha \equiv \mathrm{df} \alpha \wedge \mathrm{O} \alpha$, widzimy, że nie da się na tym gruncie definicyjnie połączyć $\mathrm{Z} \alpha \equiv$ df $\mathrm{D} \sim \alpha$. Elzenberg, z pewnych powodów, o których tu z braku miejsca nie będziemy pisać, widziałby ten związek w słabszej postaci:

z wiedzy o wartości dodatniej wynika [...] wiedza o wartości ujemnej; ale z wiedzy o wartości ujemnej nie wynika wiedza o wartości dodatniej (Elzenberg 2002b: 175).

Tezy obowiązujące w zaproponowanej semantyce różnią się znacznie od tez przyjmowanych w niektórych systemach logiki dobra. Na pewno semantyka ta nie mogłaby być semantyką dla systemu logiki dobra zaproponowanej przez Manuela Rebuschiego (2008), ponieważ nie są prawdziwe takie twierdzenia tego systemu, jak:

$$
\begin{aligned}
& \mathrm{D}(\alpha \rightarrow \beta) \rightarrow(\mathrm{D} \alpha \rightarrow \mathrm{D} \beta), \\
& \mathrm{D}(\alpha \wedge \beta) \rightarrow \mathrm{D} \alpha \wedge \mathrm{D} \beta, \\
& \mathrm{D} \sim \alpha \rightarrow \mathrm{D}(\alpha \rightarrow \beta), \\
& \mathrm{D} \alpha \rightarrow \mathrm{D}(\alpha \vee \beta) .
\end{aligned}
$$

Nie jest spełniona również specyficzna reguła inferencji tego systemu - zasada Gödla dla dobra - ponieważ zaproponowana semantyka dopuszcza uznanie za dobre jedynie sytuacji przygodnych. Nie należy przejmować się jednak niespełnianiem w semantyce relatywnej preferencji systemu Rebuschiego, ponieważ za sprawą obecności wśród tez formuł (SR1-SR4), które mają paradoksalne podstawienia, system ten należy uznać za nieadekwatną próbę uchwycenia formalnej struktury pojęcia dobra9.

Logika dobra tego typu co Rebuschiego jest odległa od przekonań Elzenberga, ponieważ zakłada $\mathrm{D} \alpha \equiv \mathrm{df} \mathrm{Z} \sim \alpha$. W logice dobra przedstawionej przez Aleksandra A. Iwina (1970: 82) porzuca się ten tradycyjny schemat definicyjny na rzecz formuły, która wiąże pojęcie dobra z pojęciem zła w następujący sposób:

$$
\mathrm{D} \alpha \rightarrow \sim \mathrm{Z} \alpha .
$$

Ten schemat jest spełniony w semantyce relatywnej preferencji. Nie wszystkie jednak formuły systemu Iwina w niej obowiązują. Na logikę ocen absolutnych Iwina składają się:

9 Formuły (SR4) i (SR3) to analogony znanych paradoksów logiki deontycznej - paradoksu Dobrego Samarytanina i Alfa Rossa. Prowadzące do problemów podstawienie (SR2) można znaleźć w (Drofiszyn 2011: 54), natomiast nieintuicyjne podstawienie (SR1) pokazuje Dariusz Łukasiewicz (2009: 672). 
(SI1)

$(\mathrm{D} \alpha \rightarrow \sim \mathrm{D} \sim \alpha)$,

$$
\mathrm{D}(\alpha \wedge \beta) \equiv \mathrm{D} \alpha \wedge \mathrm{D} \beta,
$$

$$
(\mathrm{Z} \alpha \rightarrow \sim \mathrm{Z} \sim \alpha)
$$

$$
\mathrm{Z}(\alpha \wedge \beta) \equiv \mathrm{Z} \alpha \wedge \mathrm{Z} \beta \text {, }
$$

$$
\mathrm{D} \alpha \rightarrow \sim \mathrm{Z} \alpha \text {. }
$$

Otóż nie są spełnione aksjomaty (SI2) i (SI4), ponieważ nie zachodzi jedna z implikacji składających się na te równoważności (choć zachodzą w osłabionej postaci). Należy zauważyć, że i ten system ma paradoksalne tezy. Wśród nich znajduje się $\mathrm{D} \alpha \rightarrow \sim \mathrm{Z} \beta$, wskazana przez Jerzego Kmitę (1973: 204), którą można odczytać tak, że jeśli coś jest dobre, to w konsekwencji nic nie jest złe. Obecność tej tezy dyskwalifikuje system Iwina jako adekwatną próbę oddania formalnej struktury pojęcia wartości. Nie należy zatem poczytywać za zarzut względem semantyki relatywnej preferencji tego, że nie spełnia wszystkich twierdzeń tego systemu. Należy raczej oczekiwać, że semantyka ta umożliwi poszukiwania nowych, właściwszych podstaw logiki dobra.

\section{ZŁO}

Elzenberg dostrzega również problematyczność definiowania powinności przez pojęcie wartości. Pisze:

przy takiej interpretacji zatraca się intuicyjnie uchwytny związek między powinnością i wolą [...] związek między powinnością a wolą jest nie do zanegowania. Polega on na tym, że wszelka świadomość powinności stanowi nacisk na wolę, natomiast świadomość, że „jeśli coś jest takie a takie, to jest bardziej wartościowe, niż gdyby nie było” nie stanowi takiego nacisku. [...] Nie znaczy to by myśl ta nie dostarczała nam pewnego motywu, by starać się zrealizować ów stan, ale ten motyw nie będzie miał charakteru nacisku; będzie to coś całkiem innego: „miłość” wartości” (Elzenberg 2002a: 162-163).

Innymi słowy, zaproponowany definiens powinności ma inny sens niż definiendum, co przejawia się tym, że na różne sposoby motywują wolę do działania. Powinność jest pewnego rodzaju przymusem dla woli, dlatego kojarzymy normę z nakazem, natomiast wartość jest dla niej raczej zachętą, dlatego kojarzymy ocenę z pochwałą.

Ponieważ Elzenberg był myślicielem bardzo skrupulatnym, nie od razu porzucił możliwość postawienia swojego systemu „na głowie”. Rozważał inną kontrpropozycję dla definicji wartości przez powinność. W pewnym odnale- 
zionym rękopisie zatytułowanym Uzupetnienie, pasującym treściowo do tekstu żemłosławskiego, Elzenberg rozważa propozycję definicji powinności przez zło:

jest jednak inna możliwa definicja powinności w terminach wartości ,jeżeli nie tak a tak, to źle". I tu moment nacisku zostaje wprowadzony, bo zło nie tylko budzi nienawiść, ale wywołuje nacisk w kierunku sobie przeciwnym (Elzenberg 2002a: 163).

W naszym języku formalnym możemy zaproponowaną definicję zapisać:

$$
\mathrm{O} \alpha \equiv \mathrm{df}(\sim \alpha \rightarrow \mathrm{Z} \sim \alpha) .
$$

Okazuje się, że również wszystkie równoważności o postaci $\mathrm{O} \alpha \equiv(\sim \alpha \rightarrow \mathrm{Z} \sim \alpha)$ są spełnione w semantyce relatywnej preferencji. I z tej definicji Elzenberg wydaje się niezadowolony:

warto jednak zapytać zwolenników definiowania powinności w terminach wartości, co ich może skłaniać do wyboru definicji w terminach zła, a nie dobra. Może odpowiedzą właśnie, że wtedy zachowują nacisk (Elzenberg 2002a: 164).

Reakcja woli na zło wydaje się przypominać reakcję woli na świadomość powinności, której można sprostać, niemniej jednak to jedynie nieudolne naśladowanie sensu jednego pojęcia przez drugie. Powstają bowiem dalsze trudności, jak choćby kłopotliwe wyprowadzenie pojęcia obowiązku z tak rozumianego pojęcia powinności. Dlatego Elzenberg nie rozpatruje szerzej tej definicji.

\section{DOBRO I POWINNOŚĆ}

Rozważania Elzenberga w aksjologii formalnej wieńczy konstatacja o wydźwięku negatywnym. Nie wiadomo, co uznać za pojęcie pierwotne - powinność czy wartość? Przy definiowaniu wartości przez powinność problemem pozostaje wyjaśnienie, skąd się bierze powinność pewnych sytuacji. Z kolei gdy definiujemy powinność przez wartość, kłopot sprawia wyjaśnienie pochodzenia nacisku na wolę, które jest stowarzyszone z powinnością, ale które ma zupełnie inny charakter dla wartości. To był dylemat, przed którym stanął Elzenberg. Współcześnie bogatsi o aparat formalny systemów dedukcyjnych wiemy, że możemy ten problem obejść. Wystarczy oba pojęcia włączyć do systemu jako pojęcia pierwotne i traktować aksjomaty wyrażające ich wzajemne związki jako definicje przez postulaty. Jako aksjomat możemy przyjąć choćby formułę:

(AD) $\quad \mathrm{D} \alpha \rightarrow(\alpha \wedge \mathrm{O} \alpha)$,

związaną z definicją (DP), albo formulę 
(AP)

$$
\mathrm{O} \alpha \rightarrow((\alpha \rightarrow \mathrm{D} \alpha) \wedge(\sim \alpha \rightarrow \mathrm{Z} \sim \alpha)),
$$

związaną z definicjami (PD) i (PZ) ${ }^{10}$. Obie te formuly, zgodne z istotą rozważań Elzenberga, są spełnione w semantyce przedstawionej w tej pracy.

Dla przykładu pokażemy dowód prawdziwości formuły (AD) w dowolnym modelu $\mathrm{M}$ i dowolnym świecie $u$. Załóżmy, że $(\mathrm{M}, u) \vDash \mathrm{D} \alpha$, stąd wykażemy, że $(\mathrm{M}, u) \vDash \alpha$ oraz $(\mathrm{M}, u) \vDash \mathrm{O} \alpha$. Z definicji prawdziwości formuly $\mathrm{D} \alpha$ mamy $(\mathrm{M}, u) \vDash \alpha$ oraz $\operatorname{Alt}_{u}(\sim \alpha)=\varnothing$ i dla każdego $t$ jeśli $t \in \operatorname{Alt}_{u}(\sim \alpha)$, to $\operatorname{Lep}_{u}(u, t)$. Ponieważ świat $u$ ma jedną jedyną $\alpha$-alternatywę, czyli siebie samego (wynika to ze zwrotności relacji $\mathrm{R}$ ), więc $\operatorname{Alt}_{u}(\alpha)=\varnothing$ oraz każda $\sim \alpha$-alternatywa tego świata jest gorsza od dowolnej jego $\alpha$-alternatywy. Zatem zachodzą wszystkie warunki, aby przyjąć za uzasadnione, że $(\mathrm{M}, u) \vDash \mathrm{O} \alpha$.

\section{PODSUMOWANIE}

Semantyka relatywnej preferencji daje możliwość poszukiwania nowych podstaw dla multimodalnej logiki deontyczno-aksjologicznej, w skład której wchodziłyby zarówno aksjomaty charakteryzujące pojęcia powinności i dobra, jak i aksjomaty charakteryzujące wzajemne związki między powinnością a dobrem. Przedstawiliśmy dwa takie możliwe aksjomaty: (AD) i (AP). Obie zasady są oparte na pomysłach Elzenberga i dają się opisać w semantyce inspirowanej jego przemyśleniami.

Budowanie multimodalnych logik deontyczno-aksjologicznych opiera się na założeniu o częściowej choćby niezależności porządków deontologicznego i aksjologicznego. Co ciekawe, w semantyce relatywnej preferencji dobrze widać zarówno to, co łączy deontologię i aksjologię jako dwie dziedziny sfery moralności, jak i to, co je odróżnia.

Jeśli za dobre uznajemy te sytuacje, które lepiej, że są, aniżeli miałoby ich nie być, a za powinne te, które lepiej, żeby zaszły, aniżeli miałyby nie zachodzić, to widać, że dobro, jako przynależne do sfery wartościującej, i powinność, jako przynależna do sfery rekomendującej, klasyfikują sytuacje jako lepsze i gorsze. Wspólne jest więc dla nich to, że są aktami preferencji, ale - co ważne - są aktami preferencji woli metaempirycznej, czyli są preferowaniem absolutnym czy bezwarunkowym ${ }^{11}$. Ta myśl jest zawarta $w$ relacji preferencji

\footnotetext{
${ }^{10}$ Następnik tej implikacji jest definicją pojęcia obowiązku zaproponowaną w (Chisholm, Sosa 1966: 327).

${ }^{11} \mathrm{O}$ wartości perfekcyjnej Elzenberg pisze m.in. tak: „»wartośc« [...] to zatem jakby zajmowanie pewnego szczebla w hierarchii; hierarchii nieustanowionej; według jakiegoś swoistego punktu widzenia i ze względu na jakąś swoistą cechę, ale hierarchii jak gdyby par
} 
między światami, która jest relacją pewnego rodzaju porządku na światach możliwych.

Aksjologia i deontologia, jako dwie dziedziny sfery moralności, różnią się z kolei tym, że deontologia hierarchizuje jako lepsze i gorsze to, co dopiero ma być, czyli odnosi się do przyszłości, rozważa światy postulowane, dzięki czemu pozwala uzasadniać czyny i pomaga w podejmowaniu decyzji, natomiast aksjologia hierarchizuje jako lepsze i gorsze to, co jest, na tle kontrfaktycznych światów możliwych, a więc skupia się na teraźniejszości i umożliwia ocenianie czynów.

\section{BIBLIOGRAFIA}

Brandt R. B. (1996), Etyka. Zagadnienia etyki normatywnej i metaetyki, tłum. B. Stanosz, Warszawa: Wydawnictwo Naukowe PWN.

Chisholm R. M., Sosa E. (1966), Intrinsic Preferability and the Problem of Supererogation, „Synthese” 16(3-4), 321-331. https://doi.org/10.1007/BFo0485086

Drofiszyn M. (2011), Ontologiczne założenia logiki etycznej, „Studia Philosophica Wratislaviensia" 6(1), 51-60.

Elzenberg H. (2002a), Pojęcie wartości i powinności. Tekst żemtostawski [w:] H. Elzenberg, Pisma aksjologiczne, L. Hostyński, A. Lorczyk, A. Nogal (red.), Lublin: Wydawnictwo Uniwersytetu Marii Curie-Skłodowskiej, 123-168.

Elzenberg H. (2002b), Wartość ujemna [w:] H. Elzenberg, Pisma aksjologiczne, L. Hostyński, A. Lorczyk, A. Nogal (red.), Lublin: Wydawnictwo Uniwersytetu Marii Curie-Skłodowskiej, 169-175.

Elzenberg H. (2002c), Podstawowe pojęcia aksjologii I. Wykłady toruńskie 1946-1949 [w:] H. Elzenberg, Pisma aksjologiczne, L. Hostyński, A. Lorczyk, A. Nogal (red.), Lublin: Wydawnictwo Uniwersytetu Marii Curie-Skłodowskiej, 197-257.

Elzenberg H. (2002d), Zagadnienia związane z pojęciem wartości. Wykłady 1949 [w:] H. Elzenberg, Pisma aksjologiczne, L. Hostyński, A. Lorczyk, A. Nogal (red.), Lublin: Wydawnictwo Uniwersytetu Marii Curie-Skłodowskiej, 259-303.

Goble L. (1990a), A Logic of Good, Should and Would. Part I, „Journal of Philosophical Logic” 19(2), 169-199. https://doi.org/10.1007/BFoo263540

Goble L. (1990b), A Logic of Good, Should and Would. Part II, „Journal of Philosophical Logic" 19(2), 253-276. https://doi.org/10.1007/BFoo556636

Goble L. (1993), The Logic of Obligation, „Better” and „Worse”, „Philosophical Studies” 70(2), 133-163. https://doi.org/10.1007/BFoo989587

Iwin A. A. (1970), Osnowanija łogiki ocenok, Moskwa: Izdatielstwo Moskowskogo Uniwersitieta.

Jackson F. (1985), On the Semantics and Logic of Obligation, „Mind” 94(374), 177-195. https://doi.org/10.1093/mind/XCIV.374.177

excellence, niezależnej od względów i punktów widzenia, niestanowionej” (2002a: 129). 
Kanger S. (1971), New Foundations for Ethical Theory [w:] Deontic Logic: Introductory and Systematic Readings, R. Hilpinen (red.), Dordrecht: D. Reidel, 36-58. https:// doi.org/10.1007/978-94-010-3146-2_2

Kmita J. (1973), Logika ocen, „Etyka” 11, 197-206. https://doi.org/10.14394/etyka.958

Łukasiewicz D. (2009), Źródła, zasady i perspektywy realizmu moralnego Tadeusza Czeżowskiego, „Ruch Filozoficzny” 4, 663-673.

Magdziak M. (1998), Modalności aksjologiczne [w:] Czlowiek wobec wartości $w$ filozofii Henryka Elzenberga, R. Zaborowski (red.), Warszawa: Wydawnictwo Stakroos, 147-156.

Mothersill M. (1996), The Moral Dilemmas Debate [w:] Moral Dilemmas and Moral Theory, H. E. Mason (red.), New York-Oxford: Oxford University Press, 66-85.

Rebuschi M. (2008), Czeżowski's Axiological Concepts as Full-fledged Modalities: We Must Either Make What Is Good, or Become Revisionists, „Forum Philosophicum” 13, 103-110. https://doi.org/10.5840/forphil20081317

Rönnedal D. (2017), An Introduction to Deontic Logic, Lexington.

Wiśniewski R. (1989), Henryk Elzenberg o ztu, „Ruch Filozoficzny” 46(1), 80-84.

Wolniewicz B. (1986), Myśl Elzenberga, „Studia Filozoficzne” 12, 55-73. 